\title{
Comprehensive Assessment of Waste Water Pollution Rate in Almaty City, Kazakhstan
}

\author{
Nailya A. Ibragimova, Oleg V. Esyrev, Zhanel R. Zhantuarova, and Zarema M. Biyasheva
}

\begin{abstract}
One of the constituent of the environmental safety concept in Kazakhstan is a problem of water resources depletion which is due to physiographic features such as intracontinental location, continental climate, character of relief and uneven distribution of water bodies. There are three large basins within the territory of Kazakhstan: the Caspian and Aral seas, and Lake Balkhash. The purpose of the study was assessing the quality of waste water in Almaty city (Kazakhstan) which flows to Sorbulak - the largest in the world lake-collector, from where it flows to Ili-Balkhash basin. In 2012 the southern shore of Lake Balkhash and bank of the Ili River were enrolled in the list of wetlands of global importance. A comprehensive assessment of the waste water quality in Almaty city (Kazakhstan) during the process of its complex purification: mechanical, physical-chemical and biological was made. Organoleptic, hydrochemical, microbiological and cytotoxicological methods were applied during the study. It was determined that the water inflowing to Sorbulak can be described as mild polluted at nitrogen dioxide, phosphates, lead and phenols level.
\end{abstract}

Index Terms-Waste water, mechanical purification, activated sludge, biological purification, aeration tank, return sludge, sewage.

\section{INTRODUCTION}

The significant problem in the Republic of Kazakhstan is scarcity of water resources therefore usage of treated waste water may be considered as an important alternative [1]. On the other hand the development of waste water purification system is caused by the necessity to decrease the pollution of the environment as the result of uncontrolled discharge of waste water into rivers and streams. Particularly southern bank of Ili River and shore of Lake Balkhash are in the list of wetlands of global importance.

The main purposes of waste water treatment processes are removal of coarse particles, reducing easily digestible organic wastewater fractions, e.g. nitrogen and phosphorus, removal of slowly-biodegradable organic matters and pathogenic microorganisms by activated sludge [2]. Currently, it is known that populations of microorganisms are the key components in the biogeochemical cycle of organic matter to maintain a balance in natural ecosystems [3]. Various abiotic and biotic factors influence microbiological consortium that directly affect the quality of waste water [4].

The purpose of the study is to conduct organoleptic, hydrochemical and cytotoxicological studies to assess waste water quality during it treatment including the site where waste water is discharged into the lake-collector Sorbulak.

Manuscript received May 14, 2015; revised July 14, 2015.

The authors are with the Kazakh-German University, Kazakhstan (e-mail: nailya.73@mail.ru,zarbiya@mail.ru).
The lake-collector "Sorbulak" has more than 40 years exploitation history and it is the largest in the world lake-collector for waste water. The main purpose allotted to Sorbulak depression is deep, long-term control of waste water level and conditioning natural self-purification of water for further utilization it for irrigation. Currently, every second up to 5 tons of water is discharged into "Sorbulak".

\section{General Characteristic of Purification System}

Mechanical treatment of discharged municipal waste water is taken place in a special designed department, water flows through screens as a result the water purifies from litter (paper, cellophane etc.). Then the water flows to grit chambers and flotation units. Only after mechanical treatment the water flows for biological treatment into an aeration tank a construction with a constant circulation of waste water in depth of which aerobic microorganisms grow and reproduce in activated sludge Fig. 1 to Fig. 3. Air is fed constantly into aeration tanks by pneumomechanical aeration system for the normal process of biochemical oxidation.

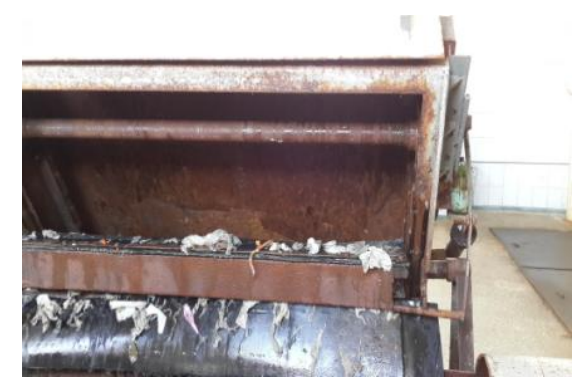

Fig. 1. Department for mechanical treatment of waste water.

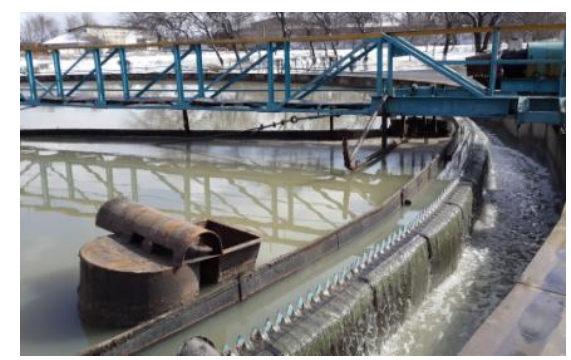

Fig. 2. Flotation unit.

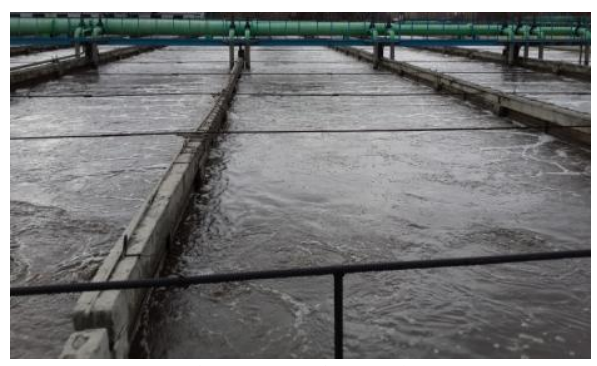

Fig. 3. Aeration tank. 
Thus, applied purification methods - mechanical, sedimentation (grit chamber) and biological treatment mutually remove up to $99 \%$ of microorganisms from initial waste water which is not enough to attain requirements established for effluent wastewater discharging and its reuse [5].

Microorganisms of various systematic groups: bacteria, fungi, rotifers, protozoa, larvae, mollusks which assemble certain relations: symbiotic (mutual) or antagonistic (adverse) are involved in the processes of biological treatment. Activated sludge has been used for 100 years as a biological treatment for domestic and industrial waste water [6]. The most numerous group of microorganisms in the activated sludge is bacteria. A number of them range within $10^{8}-10^{12}$ cells per $1 \mathrm{~kg}$ of dry sludge. More than 100 strains of bacteria may be isolated from activated sludge. As the result biocoenosis of microorganisms forms which population depends on the properties of waste water impurities, initial seeding matters and conditions of waste water treatment.

So, biological purification methods are based on an ability of microorganisms to utilize organic compounds contained in waste water as a nutrient substrate: the more activated sludge and substrate are the faster the process of biochemical oxidation is.

The process of biochemical oxidation is divided into two stages: on the first stage high concentration of substrate and accordingly high velocity of oxidation are kept. On the second stage of the treatment a deep oxidation of the organic matters remains at the lower velocity of the process. Actually the principal role of the biological purification process is metabolism which takes place inside the cells.

The process of utilization of waste water organic impurities by microorganisms consists of three stages: mass transfer of organic matters from liquid to the cell surface; diffusion of organic matter through the semipermeable membrane of the cell; metabolism of diffusing substances, and as the result there are growth of microbiological biomass, energy, carbon dioxide release etc. Bacteria involved in treatment process may induce synthesis of new specific enzymes which allow oxidizing more organic matters.

The problems of environmental safety which occur during waste water treatment are attributed to the initial precipitate and excessive sludge. "Waste water sediment" or "coarse substances of biological origin" are formed as the result of purification process which is insoluble sediment derived during purification or the following procedures of sludge stabilization. [7]. Thus, almost all chemical and microbiological pollutants concentrate in a raw sediment or initial precipitate and in an activated sludge - secondary precipitate.

Initial and secondary precipitates are coagulated while generation of biosludge which is further transported to irrigation fields located, as a rule, not far from a collector. Later when biosludge dries out naturally, transmission of pollutants into soil, ground water and also air due to carrying of sprays and microorganisms and their metabolites is taken place. Such way of biosludge utilization is considered to be ecologically and hygienic dangerous.

It is known that stabilized sludge of waste water destined for agricultural needs should be thoroughly controlled for high concentration of metals (cadmium, arsenic, copper, lead, mercury and zinc), impervious organic pollutants (aldrin chlorineorganic compounds, dieldrin, heptachlor, DDT and lindane) and pathogenic microorganisms (bacteria, viruses, protozoa and helminths) to prevent their transfer along the food chain [8].

Waste water sediment usually contains many pathogenic bacteria such as Salmonella spp., Listeria spp., Escherichia coli, Campylobacter spp., Clostridium spp., и Yersinia spp., most of them are zoonosis [9].

\section{METHODOLOGY}

\section{A. Materials}

This study used water sampled after mechanical treatment, from aerotank, after biological treatment and from the ditch filled with non-activated return sludge in a clear day on the $12^{\text {th }}$ of March 2015

\section{B. Study Methods and Experimental Facilities}

Organoleptic parameters were determined according to standard methods.

Hydrological method: acidity was determined by $\mathrm{pH}$-метр SenTix 51,52/pH 32103 TW- Set; dissolved oxygen was measured by OX 13210/CELLOX 325-3; electroconductivity was measured by conductometer TetraCon 325/Cond 3110 SET2.

Hydrochemical method: nitrogen oxides $\left(\mathrm{NO}_{2}, \mathrm{NO}_{3}\right)$, sulphur oxide $\left(\mathrm{SO}_{4}\right)$, phosphates, lead ions, cadmium ions, phenols were determined by spectrophotometer Spectroquant Spectro Pharo 100, Merck, wave length 320-1100 nm and by analyzer $\mathrm{BOD}_{5}$ OxiTop 12.

Microbiological analysis was conducted according to standard methods.

Cytotoxic method: to determine cytotoxic exposure on growth and roots length dicotyledonous plant watercress (Lepidium sativum), Cruciferae (Brassicaceae) was used.

Statistic was made according to Student t-Test.

\section{RESULTS AND DISCUSSION}

\section{A. Organoleptic and Hydrochemical Studies Results}

The odour of waste water is specific for sewage -mixture of faeces odour and odour of fat decomposition, detergents, soaps etc. Organoleptic study was conducted at the ambient temperature $20.2^{\circ} \mathrm{C}$ (see Table I).

Electroconductivity values are not standardized and only depend on concentration of metal ions in the initial water. After mechanical treatment in studied water samples electroconductivity was a little higher and was getting lower in the sample from an aeration tank and a ditch with non-activated return sludge which probably due to accumulation of metals by microorganisms contained in the water. Moreover, in all samples of tested water electroconductivity value turned out to be significantly higher

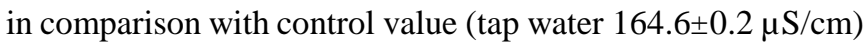
(see Table II).

Water acidy of open sources is within a $\mathrm{pH}$ range from 6 to 9. $\mathrm{pH}$ values of tested samples were almost equal, it was 
within $6.0 \mathrm{pH}$ range which is lower than $\mathrm{pH}$ value of tap water which is 7.7.

TABLE I: ORGANOLEPTIC PARAMETERS OF WASTE WATER

\begin{tabular}{|c|c|c|c|c|}
\hline Parameters & After mechanical treatment & From aerotank & After biological treatment & $\begin{array}{l}\text { Non-activated return } \\
\text { sludge (regenerated) }\end{array}$ \\
\hline Odour intensity & $\begin{array}{l}1481.5 \\
\text { faecal } \\
\text { (sewage) }\end{array}$ & $\begin{array}{l}60.6 \\
\text { oozy }\end{array}$ & 2 & $\begin{array}{l}400 \\
\text { marsh (oozy) }\end{array}$ \\
\hline Coloration & Grayish yellow & Colourless & Colourless & $\begin{array}{l}\text { Grayish with dark brown } \\
\text { flocks }\end{array}$ \\
\hline Turbidity & Turbit & Transparent & Transparent & Turbit \\
\hline Sediment & $\begin{array}{l}\text { Approx. 1-2 mm, grayish } \\
\text { yellow, slime }\end{array}$ & $450 \mathrm{~mm}$ & $\begin{array}{l}\text { Approx. } 1 \mathrm{~mm} \text {, single } \\
\text { flocks }\end{array}$ & $1000 \mathrm{~mm}$ \\
\hline Transparency, cm & $5.5 \pm 1.0$ & $3.8 \pm 0.5$ & $23.3 \pm 1.2$ & Indistinct \\
\hline
\end{tabular}

TABLE II: HYDROLOGICAL PARAMETERS OF WASTE WATER

\begin{tabular}{lllc}
\hline \hline Parameters & After mechanical treatment & From aerotank & After biological treatment \\
\hline $\begin{array}{l}\text { Specific conductivity, } \\
\mu \mathrm{S} / \mathrm{cm}\end{array}$ & $921.3 \pm 4.0$ & $792.3 \pm 7.7$ & $821.3 \pm 3.8$ \\
$\mathrm{pH}$ & $6.6 \pm 0.07$ & $6.6 \pm 0.67$ & $6.6 \pm 0.60$ \\
sludge (regenerated) & $6.9 \pm 0.69$ \\
Dissolved oxygen, $\mathrm{mg} / \mathrm{L}$ & $0.38 \pm 0.03$ & $0.76 \pm 0.05$ & $1.38 \pm 0.02$ \\
\hline \hline
\end{tabular}

The highest concentration of dissolved oxygen was in water sampled after biological treatment which probably due to oxygen emitting from bacterial mass accumulated in aeration tank. However, this value is lower than standard value for open water sources (should be not lower than 4 $\mathrm{mg} / \mathrm{dm}^{3}$, in any season in the sample taken till midday) and is significantly lower than control value (tap water) [10].

Concentration values of dissolved oxygen in the water with non-activated return (regenerated) sludge and in the household water (after mechanical treatment) were almost equal which probably due to microorganisms in a ditch filled with non-activated return (regenerated) sludge which "are ready" to be transferred in to a tank and cause eutrophication process (see Table II).

Concentrations of nitrogen dioxide in water sampled after mechanical treatment and from aerotank are higher than standard value, which are 4.9 MPC and 2.8 MPC correspondingly. It should be mentioned that $\mathrm{NO}_{2}$ concentration in water sampled from the site where waste water is discharged to Sorbulak is lower than $1.0 \mathrm{mg} / \mathrm{L}$. Concentration of $\mathrm{NO}_{2}$ is only $0.4 \mathrm{MPC}$ in the water sampled from a ditch with non-activated return (regenerated) sludge. Such low concentration is due to binding this acid oxide by microorganisms so as exactly in the ditch there is a so-called "hungry sludge" (see Table III).

As for nitrate radical $\mathrm{NO}_{3}$ there is no increase in values in comparison to standard in all samples of studied water (see Table III). However, the highest concentration is determined in the water sampled from a ditch with non-activated return (regenerated) sludge which is $3.7 \mathrm{mg} / \mathrm{L}$.

Concentration of sulphur dioxide does not exceed MPC value in all tested samples. Likewise the highest value was in water sampled from a ditch with non-activated return (regenerated) sludge which is $98 \mathrm{mg} / \mathrm{L}$.

Maximal exceeding of standard values was determined while measuring the concentration of phosphates: in water sampled after mechanical treatment it was $3.2 \mathrm{MPC}$, after biological treatment $-3.5 \mathrm{MPC}$, from aeration tank -4.5 MPC and from a ditch with non-activated return (regenerated) sludge - 11.9 MPC (see Table III).

According to $\mathrm{BOD}_{5}$ and depending on water pollution index water sampled after mechanical treatment is classified as "extremely polluted", $\mathrm{BOD}_{5}>10.0$. As for water sampled from aeration tank and a ditch filled with non-activated return (regenerated) sludge, it is "polluted" $\left(\mathrm{BOD}_{5}\right.$ 6.0-10.0), however the value does not exceed the standard for recreation zones. The water sampled after biological treatment has $\mathrm{BOD}_{5} 2.3$ which is determined as "mild polluted" $\left(\mathrm{BOD}_{5}\right.$ 1.0-2.0).

Thus, according to studied biogenic components there is exceeding of standard values at nitrogen dioxide and phosphates after biological treatment (in the site where waste water is discharged into Sorbulak). Increased concentration values of nitrates, sulphates and polyphosphates are determined in water sampled from a ditch filled with non-activated return (regenerated) sludge.

Results of metals concentrations determination in water samples are represented in Table IV.

It was determined that concentration of lead ions was 45.7 MPC in water sampled after mechanical treatment, 24.0 MPC - from aerotank, $18 \mathrm{MPC}$ - after biological treatment and 32.0 MPC - from a ditch with non-activated return (regenerated) sludge. Decreasing in lead concentration may be explained due to its binding with activated sludge during water treatment process (from mechanical to biological). However, water with significantly high concentration of this heavy metal is discharged into Sorbulak.

Though, the concentration of other heavy metal - cadmium in the water sampled after biological treatment does not exceed the standard value. Cadmium concentrations in other water samples are: $270.0 \mathrm{MPC}$ - after mechanical treatment, 40.0 MPC for water sampled from aeration tank and 60.0 MPC - from a ditch with non-activated return (regenerated) sludge. 
It was determined that concentration of phenols in all tested samples exceeded a standard value and was 1580.0 MPC in the water sampled after mechanical treatment, 380.0 MPC - from aerotank, 420.0 MPC - after biological treatment and 1110.0 MPC - a ditch with non-activated return (regenerated) sludge (see Table IV).

TABLE III: HYDROCHEMICAL PARAMETERS OF WASTE WATER

\begin{tabular}{|c|c|c|c|c|}
\hline Parameters & After mechanical treatm & From aerotank & $\begin{array}{l}\text { After biological } \\
\text { treatment }\end{array}$ & $\begin{array}{l}\text { Non-activated return } \\
\text { sludge (regenerated) }\end{array}$ \\
\hline $\begin{array}{l}\mathrm{NO}_{2}, \mathrm{mg} / \mathrm{L} \\
\mathrm{MPC} 3.3 \mathrm{mg} / \mathrm{L}\end{array}$ & $16.2 \pm 0.2$ & $9.3 \pm 0.3$ & Less than $1,0 \mathrm{mg} / \mathrm{L}$ & $1.5 \pm 0.1$ \\
\hline $\begin{array}{l}\mathrm{NO}_{3}, \mathrm{mg} / \mathrm{L} \\
\mathrm{MPC} 45.0 \mathrm{mg} / \mathrm{L}\end{array}$ & $0.5 \pm 0.1$ & $2.0 \pm 0.4$ & $2.6 \pm 0.1$ & $3.7 \pm 0.5$ \\
\hline $\begin{array}{l}\left.\text { Polyphosphates (at } \mathrm{PO}_{4} \sim\right) \text {, } \\
\mathrm{mg} / \mathrm{L} \\
\text { MPC } 3.5 \mathrm{mg} / \mathrm{L}\end{array}$ & $11.1 \pm 0.9$ & $15.7 \pm 2.6$ & $12.3 \pm 0.9$ & $41.6 \pm 1.2$ \\
\hline $\begin{array}{l}\mathrm{SO}_{4}, \mathrm{mg} / \mathrm{L} \\
\mathrm{MPC} 500.0 \mathrm{mg} / \mathrm{L}\end{array}$ & $85.6 \pm 3.5$ & $69.0 \pm 0.6$ & $64.6 \pm 2.3$ & $98.0 \pm 1.0$ \\
\hline $\begin{array}{l}\mathrm{BOD}_{5}, \mathrm{mgO}_{2} / \mathrm{dm}^{3}, \mathrm{MPC} \\
6,0 \mathrm{mgO}_{2} / \mathrm{dm}^{3}, \\
\text { for recreation zones }\end{array}$ & $11.0 \pm 1.0$ & $5.6 \pm 0.9$ & $2.3 \pm 0.4$ & $6.0 \pm 0.0$ \\
\hline Parameters & After mechanical treatment & From aerotank & After biological treatment & $\begin{array}{l}\text { Non-activated return } \\
\text { sludge (regenerated) }\end{array}$ \\
\hline $\begin{array}{l}\mathrm{Pb}^{+2}, \mathrm{mg} / \mathrm{L} \\
\mathrm{MPC} 0.03 \mathrm{mg} / \mathrm{L}\end{array}$ & $1.37 \pm 0.04$ & $0.72 \pm 0.07$ & $0.54 \pm 0.02$ & $0.96 \pm 0.01$ \\
\hline $\begin{array}{l}\mathrm{Cd}^{+2}, \mathrm{mg} / \mathrm{L} \\
\mathrm{MPC} 0.001 \mathrm{mg} / \mathrm{L}\end{array}$ & $0.27 \pm 0.03$ & $0.04 \pm 0.01$ & & $0.06 \pm 0.00$ \\
\hline $\begin{array}{l}\text { Phenols, mg/L } \\
\text { MPC } 0.001 \mathrm{mg} / \mathrm{L}\end{array}$ & $1.58 \pm 0.01$ & $0.38 \pm 0.05$ & $0.42 \pm 0.15$ & $1.11 \pm 0.12$ \\
\hline $\begin{array}{l}\mathrm{SO}_{4}, \mathrm{mg} / \mathrm{L} \\
\mathrm{MPC} 500.0 \mathrm{mg} / \mathrm{L}\end{array}$ & $85.6 \pm 3.5$ & $64.6 \pm 2.3$ & $69.0 \pm 0.6$ & $98.0 \pm 1.0$ \\
\hline $\begin{array}{l}\mathrm{BOD}_{5}, \mathrm{mgO}_{2} / \mathrm{dm}^{3} \text {, } \\
\text { MPC } \\
6,0 \mathrm{mgO}_{2} / \mathrm{dm}^{3} \text {, for } \\
\text { recreation zones }\end{array}$ & $11.0 \pm 1.0$ & $5.6 \pm 0.9$ & $2.3 \pm 0.4$ & $6.0 \pm 0.0$ \\
\hline
\end{tabular}

Thus, determination of heavy metals concentration in water samples shows a significant exceeding of MPC values at lead and cadmium levels as well as substantial increasing of phenols concentration. It was proved that exactly activated sludge accumulated considerable amount of biogenic and anthropogenic pollutants.

\section{B. Microbiological Studies Results}

Biological method of waste water purification is based on applying specific biological population which is activated sludge (biofilm) used for deep purification as organic as inorganic pollutants. Activated sludge is dark-brown flocks of several hundreds micrometers in size consists of $70 \%$ of living organisms and $30 \%$ of inorganic solid particles. Living organisms together with solid substrates on which they dwell form so-called zoogloea and establish complex interactions between microbal populations contained in waste water e.g. carnivorism which occurs between protozoa and bacteria or competition - between bacteria, etc [11]

Microorganisms of various genera were determined: Pseudomona, Bacillus, Arthrobacter, Pseudomonas, Actinomyces, Corynebacterium, Desulfotomaculum, Micrococcus Bacillus Sarcina, Mycobacterium

\section{Flavobacterium, Achromobacter.}

\section{Cytotoxicological Study Results}

The smallest number of watercress germinating roots longer than $0.5 \mathrm{~cm}$ grew in the water sampled after mechanical treatment. However, the number of "burst out" roots in this group was the largest. In other water samples the number of roots was from 16 to 29 which length was more than $0.5 \mathrm{~cm}$. Up to $14 \pm 2$ seeds did not spire in the water sampled from aerotank at all.

It should be mentioned that most seeds cultivated in tap water spired and their length was within the range from 2.5 to $5.5 \mathrm{~cm}$.

\section{CONCLUSION}

Exceeding the standard values at nitrogen dioxide and phosphates level (biogenic elements) as well as lead, cadmium and phenols concentrations was found in the samples from the site where waste water is discharged into the lake-collector Sorbulak. Microbiological consortium was determined consisting mostly of such microorganisms genera as Pseudomonas, Bacillus, Corynebacterium, Actimomyces, 
Micrococcus Bacillus, Mycobacterium and Flavobacterium. The water sampled after each stage of purification has certain cytotoxicological properties: from total inhibition of roots growth up to "burst out" roots of watercress including uneven growth of main and lateral roots.

Considerable amount of discharge sludge and initial precipitate are stored on the out-of-used agricultural lands. Due to it the best way to control these waste is anaerobic fermentation. It is well known that anaerobic fermentation is a natural biological process as the result of which complex organic matters are decomposed into simple components by mutual effect of metabolically bind microorganisms of four groups which are hydrolytic, acidogenic, acetogenic and methanogenic. The result of such process is the production of renewable source of energy (biogas) and formation of nonpathogenic nourishing fertilizer [12], [13].

Currently, application of residual sludge for biogas production is studied.

\section{REFERENCES}

[1] Concept for transition of the Republic of Kazakhstan to Green Economy. [Online]. Available: http://www.led-ca.net/assets/files/Concept_Rus-GreenEcon-Kaz.pdf

[2] A. Muela, M. Orruño, M. L. Alonso, M. Pazos, I. Arana, and R. M. Alonso, "Microbiological parameters as an additional tool to improve wastewater treatment plant monitoring," Ecol. Indicators, vol. 11, pp. 431-437, March 2011.

[3] A. D. Kent, A. C. Yannarell, J. A. Rusak, E. W. Triplett, and K. D. McMahon, "Synchrony in aquatic microbial community dynamics," ISME J., vol. 1, no. 1, pp. 38-47, May 2007.

[4] P. Wanjugi and V. J. Harwood, "The influence of predation and competition on the survival of commensal and pathogenic fecal bacteria in aquatic habitats," Environ Microbiol., vol. 15, pp. 517-526, Feb. 2013.

[5] V. Lazarova, P. Savoye, M. I. Janex, E. R. Blatchley, and M. Pommepuy, "Advanced wastewater disinfection technologies: State of the art and perspectives," Water. Sci. Technol., vol. 40, pp. 203-214, Nov. 1999

[6] H. Hauduc, S. Gillot, L. Rieger, A. Shaw, I. Takacs, and S. Winkler, "Activated sludge modelling in practice: An international survey," Water. Sci. Technol., vol. 60, pp. 1943-1951, Oct. 2009.

[7] S. Arcak, E. Karaca, and C. Tu"rkmen, "A study on potential agricultural use of sewage sludge of Ankara wastewater treatment plant," in Proc. the International Symposium on Desertification, Turkey, pp. 345-349, June 2000.

[8] M. Saleem, M. H. Al-Malack, and A. A. Bukhari, "Seasonal variations in the microbial population density present in biological sludge," Environ. Technol., vol. 22, pp. 255-259. 2001.

[9] T. M. Straub, I. L. Pepper, and C. P. Gerba, "Hazards from pathogenic microorganisms in land-disposed sewage sludge," Rev. Environ. Contam. Toxicol., vol. 132, pp. 55-91, Feb. 1993.

[10] About the approval of the Sanitary regulations sanitary and epidemiological requirements to water sources, water intake sites for household water use and community water use, and water objects safety, Resolution of the Government of the Republic of Kazakhstan, January 18, 2012.

[11] R. M. Atlas and R. Bartha, Microbial Ecology: Fundamentals and Applications, Menlo Park: Benjamin Cummings Science Publishing, 1997, p. 640.

[12] J. Guo, Y. Peng, B. J. Ni, X. Han, L. Fan, and Z. Yuan, "Dissecting microbial community structure and methane-producing pathways of a full-scale anaerobic reactor digesting activated sludge from wastewater treatment by metagenomic sequencing," Microb. Cell Fact., vol. 14, no. 1, p. 33, March 2015.

[13] W. Lv, F. L. Schanbacher, and Z. Yu, "Putting microbes to work in sequence: Recent advances in temperature-phased anaerobic digestion processes," Bioresour. Technol., vol. 101, no. 124, pp. 9409-9414, Dec. 2010.

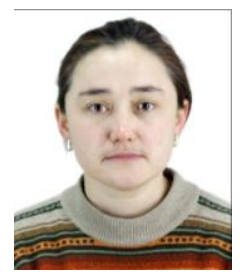

Nailya A. Ibragimova was born in 1973 in Alma-Ata, Kazakhstan. In 2002, she received her master degree with honors in biology from the Kazakh National University named after Al-Farabi. She is a doctor of biological science since 2007. Since 2004 to now, she has been working in the field of ecology and sustainable development in the Kazakh-German University, Almaty, Kazakhstan. Her professional interests cover toxicological studies of environment and "green" technologies. She is an author of more than 40 scientific articles which were published in republic and international journals.

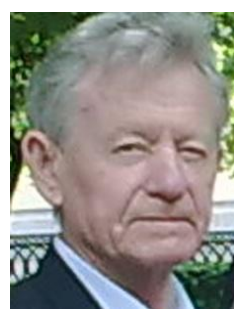

Oleg V. Esirev was born in 1939. He is a doctor of biological science, professor, academician of International Academy of Higher Education. In 1961 he graduated from the Kazakh National University named after S.M. Kirov, Biological Department. Since 1975, he is involved in both scientific and educational activities. His scientific interests are biochemistry, biotechnology, ecology and water system issues. He has more than 200 scientific publications including one monograph.

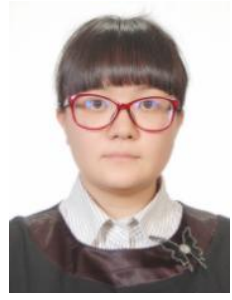

Zhanel R. Zhantuarova was born in Almaty, Kazkhstan. In 2007 she graduated from the Kazakh National University named after Al-Farabi, Biological Department. After graduation, she was employed as a laboratory assistant at the Scientific Centre. In 2014 she graduated from the Cyprus International University, Environmental Science Department. After graduation from the CIU, she was offered a work as the deputy head of GLP QA Department.

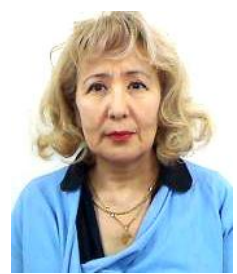

Zarema M. Biyasheva graduated from the Kazakh National University named after S.M. Kirov, Biological Department in 1975. In 1978 she completed her postgraduate study in Institute of Cytology and Genetics of the Siberian Department of RAS in Novosibirsk where she also defended a graduation project. Later on she became an associate professor in the Kazakh National University named after Al-Farabi. Her research interests include but not limited to the biological identification the problem areas of Kazakhstan. She has more than 80 publications including 4 tutorials. 